\title{
Common mental disorder among incarcerated women: a study on prevalence and associated factors
}

\author{
Transtorno mental comum entre mulheres encarceradas: \\ estudo de prevalências e fatores associados
}

Celene Aparecida Ferrari Audi ${ }^{1}$

Silvia Maria Santiago ${ }^{1}$

Maria da Graça Garcia Andrade ${ }^{1}$

Priscila Maria Stolses Bergamo Francisco ${ }^{1}$

${ }^{1}$ Departamento de Saúde Coletiva, Faculdade de Ciências Médicas, Universidade Estadual de Campinas. R. Tessália Vieira de Camargo 126, Cidade Universitária Zeferino Vaz. 13083-887 Campinas SP Brasil.

celenefaudi@yahoo.com.br

\begin{abstract}
Mental disorders are present in four of the ten main causes of incapacity across the world. This article aims to analyze the prevalence of Common Mental Disorders (CMD) in incarcerated women and associated factors. A cross-sectional study was conducted with a population of 1,013 women incarcerated in a female prison. The prevalence of CMD was assessed by the SRQ-20. The hierarchical logistic regression was the method of analysis used to search for independent associations between sociodemographic, lifestyle, morbidity and violence variables with CMD and strength of association. The prevalence of CMD was $66.7 \%$. The following variables were independently and positively associated with CMD: lack of income, hypertension, tranquilizers, physical inactivity, smoking, scabies/pediculosis, psychological violence in the year before being arrested, and having witnessed psychological violence in the family in childhood/adolescence. Interdisciplinary activities among health, justice and education institutions can contribute to a qualified assessment of women before admission into the prison system. This can enable an approach that does not exacerbate or trigger the onset of CMD, contributing to the improvement in living conditions and for better health and recovery strategies. Key words Women's health, Mental health, Common mental disorder, Violence, Prison
\end{abstract}

Resumo Transtornos mentais estão presentes em quatro das dez principais causas de incapacidade em todo o mundo. O objetivo deste artigo é analisar a prevalência e os fatores associados ao transtorno mental comum entre mulheres encarceradas. Método: estudo transversal realizado com uma população de 1.013 mulheres encarceradas em uma prisão feminina. A prevalência de TMC foi avaliada através do SQR-20. O modelo de regressão logística hierárquica foi o método de análise utilizado para verificar associações independentes entre as variáveis sociodemográfica, estilo de vida, morbidade e violencia com TMC e sua força de associação. A prevalência de TMC foi de $66,7 \%$. Foram de forma independente e positivamente associadas com TMC as variáveis: falta de renda, hipertensão, uso de tranquilizantes, sedentarismo, tabagismo, sarna/pediculose, violência psicológica no ano antes de ser presa e ter testemunhado violência psicológica na família quando criança/adolescente. Atividades interdisciplinares entre as instituições de saúde, justiça e educação podem contribuir para uma avaliação qualificada das mulheres antes da admissão no sistema prisional, assim como contribuir para a melhoria das condições de vida e de melhores estratégias de saúde e recuperação.

Palavras-chave Saúde da mulher, Saúde mental, Trantorno mental comum, Violência, Prisão 


\section{Introduction}

Mental and behavioral disorders are a set of diseases defined by the International Classification of Diseases (ICD-10). Although the symptoms vary considerably, such behaviors are characterized, generally speaking, by a combination of abnormal ideas, emotions, behaviors and relationships with other people. The dichotomy between the biological and psychosocial dimensions has been an obstacle to the understanding of mental and behavioral disorders ${ }^{1}$.

Ordinary mental disorders are characterized by non-psychotic psychiatric symptoms, as insomnia, fatigue, irritability, forgetfulness, difficult concentration, anxiety and somatic complaints ${ }^{2}$. In fact, these disturbances are similar to many physical diseases that result from a complex interaction of all these factors ${ }^{1}$.

Mental disorders are present in four of the ten main causes of incapacity across the world, a situation that represents high costs in terms of human suffering, work disability and economic losses $^{1}$.

This condition can be aggravated among incarcerated individuals. Today, approximately nine million people worldwide are held in prisons. At least half of them have personality disorders and one million prisoners or more across the world suffer from severe mental disorders, like psychosis or depression. Furthermore, each year millions of prisoners try to end their lives while they are in prison ${ }^{3-5}$.

A systematic review that evaluated 62 studies conducted in 12 countries, including 22,790 prisoners, has found that $3.7 \%$ of men had psychotic disorders, $10 \%$ had major depression, and $65 \%$ had personality disorder, including $47 \%$ who suffered from antisocial personality disorder. Among women, $4 \%$ had psychotic disorders, $12 \%$ had major depression, and $42 \%$ had personality disorder, including $21 \%$ who suffered from antisocial personality disorder ${ }^{6}$.

In a study carried out by Meltzer and Petticrew $^{7}$, only one prisoner out of ten did not show evidences of having mental disorders, and not more than two out of ten had only one disorder.

The reasons for this high prevalence have been discussed by Reed ${ }^{8}$ and include: higher risk of incarceration for people with mental disorder, insufficient assessment by courts, inefficient healthcare services, and non-identification of mental problems in the moment of imprisonment.

Among TMC associated factors stand out to be women, low education level, physical inactivi- ty, alcoholic consumption, smoking, medication use, stressful events in life and social isolation ${ }^{9,10}$.

Thus, prisons are clearly associated with mental health problems, either because many imprisoned individuals already had such disorders, or because people without mental disorders may develop emotional problems during the incarceration period due to the regime and conditions of the prison environment $t^{5,10,11}$.

In view of the scarce scientific production on the theme in Brazil and of its epidemiologic relevance, it has become pertinent to investigate it, especially in the population of incarcerated women, besides that, to identify these factors can guide relevant interventions.

The aim of the present study was to assess the prevalence of Common Mental Disorder (CMD) among incarcerated women and to investigate its association with sociodemographic characteristics, self-reported morbidity and weight gain, variables related to lifestyle, use of tranquilizers and prior use of illicit drugs, as well as types of violence suffered before incarceration.

\section{Methods}

\section{Study design}

A cross-sectional study was conducted from August 2012 to July 2013 with total of inmates (n $=1,013)$ at a Female Prison (FP) located in the county of Campinas, São Paulo State. This study is part of a larger research that investigated health conditions of incarcerated women and workers at the institution.

\section{Questionnaire, instrument, measurements and variables}

The information was collected by means of a questionnaire that was divided into modules, administered by trained interviewers and answered face-to-face by the incarcerated women. The questionnaire addressed demographic characteristics (age, religion, marital status, race/skin color), socioeconomic characteristics (level of schooling, occupation in the FP and income), length of imprisonment, health-related behaviors, life and health conditions in the prison, and prior situation of violence, among others.

In the present study, the dependent variable was Common Mental Disorder (CMD), assessed by means of the Self-Reporting Questionnaire 20 (SRQ-20), an instrument developed by the 
World Health Organization (WHO) ${ }^{12}$ to detect common mental disorders in the general population. Validated by Mari and Willians $s^{13}$ in the city of São Paulo, SRQ-20 is recommended by the $\mathrm{WHO}^{1}$ to be used in developing countries and it has proved to be efficient to screen and detect common mental disorders.

An advantage of using SRQ-20 is that the instrument has been validated in Brazilians living in urban environments and has presented high sensitivity and specificity. The instrument is composed of 20 questions with dichotomous answers (yes/no) about depressive-anxious mood, somatic symptoms, decline in vital energy and depressive thoughts. Each answer "yes" is scored the value " 1 ", and the final score is the sum of positive answers, ranging between 0 and $20^{12}$.

The score used to assess CMD in this study was $\geq 8$. A study that evaluated the performance of SRQ-20 as a psychiatric screening instrument has shown an ideal cut-off point of $7 / 8$, with sensitivity of $86.33 \%$ and specificity of $89.31 \%$. The SRQ-20's discriminating power for psychiatric diagnosis was 0.91 . Cronbach's alpha coefficient was 0.86 , the positive predictive value was $76.43 \%$ and the negative predictive value was $94.21 \%{ }^{13}$.

The following independent variables were considered:

- Sociodemographic: age group $(\leq 39$ years; $\geq 40$ years), is currently studying (yes/no), has completed primary education (yes/no), marital status (married/stable union, other), children (yes/no), skin color (white, non-white), religion (Catholic, other), works (yes/no), receives income (yes/no), length of permanence in the Prison ( $\leq 1$ year, $>1$ year), length of imprisonment $(\leq$ 1 year, $>1$ year $)$.

- $\quad$ Self-reported morbidity: It was asked women if they had arterial hypertension, diabetes mellitus, heart problem, gynecological problem, vaginal bleeding, urinary tract infection, fractures, tuberculosis, Hansen's disease, IST/AIDS, scabies/pediculosis. Considering overweight or obesity, they were calculated by the measure of height and weight $\left(B M I=\mathrm{kg} / \mathrm{m}^{2}\right)$.

- Lifestyle: practice of physical activity $\geq$ 150 minutes weekly, smoking, use of tranquilizers, risky sexual behavior (to have sex without condom and have multiple partners), and prior use of illicit drugs (dichotomized as yes/no).

- Types of violence suffered before imprisonment: psychological, physical, sexual (dichotomized as yes/no). In the assessment of prior violence, the questions referred to childhood or adolescence (before the age of 15) and the indi- cators were 'has witnessed physical aggression in the family' (yes/no) and 'has suffered physical aggression in the family scope' (yes/no).

\section{Statistical analyses}

The collected information was keyboarded in the statistical package Epi Info 2000. Subsequently, the consistency of the database was analyzed, and whenever necessary, the questionnaires referring to the interviews were revisited. The software SPSS version 17.0 (SPSS Chicago, Illinois, USA) was employed for the statistical analyses. Initially, descriptive analyses were carried out, and the prevalence and bivariate association tests were calculated by means of the chi-square test, with a level of significance of $5 \%$.

Analyses were performed using a hierarchical multiple logistic regression model developed in four stages.

In the first stage, we introduced the socioeconomic, biological, sociodemographic, and length of imprisonment variables that presented a level of significance lower than $20 \%(p<0.20)$ in the test of association with the dependent variable. The variables with $p<0.05$ remained in the model.

In the second stage, besides the variables that had remained in the previous stage, the self-reported morbidity variables were added, and those with $p<0.05$ remained in the model.

In the third stage, the variables concerning health-related behaviors were included, and those with $\mathrm{p}<0.05$ remained in the model.

In the fourth and last stage, the variables related to situations of violence experienced by the inmates before the incarceration were included, and those with $\mathrm{p}<0.05$ remained in the model.

The strength of the association between the independent variables and the dependent variables was expressed in Odds Ratio values, with a 95\% confidence interval. Model adjustment was verified by the Hosmer-Lemeshow Test.

The Project was submitted to the Research Ethics Committee of the Prisons Administration Department on October 27, 2011 and was approved on June 21, 2012. The consent document was read to all the interviewees. The document explained the aims of the study, the themes that would be approached and the procedures that would be followed. Voluntary participation was guaranteed, as well as the secrecy of participants' identity and the possibility of abandoning the study at any time, without any penalization or need of justification. 


\section{Results}

The prevalence of common mental disorder (CMD) found in the women incarcerated at the institution considered in the present study was $66.7 \%$.

The average age of the 1,013 researched women was $30.8(\mathrm{sd}=9.3)$ years. According to Table 1 , the majority of the women were aged 39 years or younger $82.0 \%$, were single $65.0 \%$ ), reported that their skin color was non-white $51.9 \%$, had not completed primary education $63.0 \%$ with up to three years of study), was not studying in the Prison 95.8\%, was not receiving any income $64.0 \%$, and did not have any occupational activity in the Prison $88.5 \%$. Among the interviewees, $3.0 \%$ were pregnant and $80.3 \%$ of them reported being mothers. Length of permanence in the Prison was lower than or equal to 1 year for $60.8 \%$ of the interviewees. In the simple analysis, the women who reported absence of income received for working in the FP presented higher prevalence of CMD.

In relation to the prevalence of common mental disorder (CMD) according to self-reported morbidity and weight gain, a higher preva-

Table 1. Sociodemographic characteristics, length of imprisonment and prevalence of common mental disorder (CMD) among female inmates of a prison in the interior of the State of São Paulo, 2011/2013.

\begin{tabular}{|c|c|c|c|c|c|}
\hline \multirow{2}{*}{ Variables and categories } & \multicolumn{2}{|c|}{ Inmates $(n=1,013)$} & \multicolumn{2}{|c|}{ CMD $(\geq 8)$} & \multirow{2}{*}{ P-value ${ }^{*}$} \\
\hline & $\mathbf{n}$ & $\%$ & $\mathbf{n}$ & $\%$ & \\
\hline Age group ${ }^{*}$ & & & & & 0.095 \\
\hline$\leq 39$ years & 826 & 82.0 & 560 & 67.8 & \\
\hline$\geq 40$ years & 181 & 18.0 & 111 & 61.3 & \\
\hline Studies in prison & & & & & 0.588 \\
\hline No & 969 & 95.8 & 647 & 66.8 & \\
\hline Yes & 43 & 4.2 & 27 & 62.8 & \\
\hline Has completed primary education & & & & & 0.841 \\
\hline No & 622 & 63.0 & 413 & 66.4 & \\
\hline Yes & 391 & 37.0 & 262 & 67.0 & \\
\hline Marital status & & & & & 0.620 \\
\hline Married/stable union & 355 & 35.0 & 233 & 65.6 & \\
\hline Other & 658 & 65.0 & 442 & 67.2 & \\
\hline Children & & & & & 0.964 \\
\hline No & 200 & 19.7 & 133 & 66.5 & \\
\hline Yes & 813 & 80.3 & 542 & 66.7 & \\
\hline Skin color ${ }^{*}$ & & & & & 0.205 \\
\hline White & 487 & 48.1 & 315 & 64.7 & \\
\hline Non-white & 526 & 51.9 & 360 & 68.4 & \\
\hline Catholic religion & & & & & 0.637 \\
\hline No & 613 & 60.5 & 405 & 66.1 & \\
\hline Yes & 400 & 39.5 & 270 & 67.5 & \\
\hline Works in prison & & & & & 0.786 \\
\hline No & 897 & 88.5 & 599 & 66.8 & \\
\hline Yes & 116 & 11.5 & 76 & 65.5 & \\
\hline Receives income & & & & & 0.020 \\
\hline No & 646 & 64.0 & 447 & 69.2 & \\
\hline Yes & 363 & 36.0 & 225 & 62.0 & \\
\hline Length of permanence in prison & & & & & 0.150 \\
\hline$<1$ year & 616 & 60.8 & 421 & 68.3 & \\
\hline$\geq 1$ year & 397 & 39.2 & 254 & 64.0 & \\
\hline Length of imprisonment & & & & & 0.673 \\
\hline$<1$ year & 838 & 82.7 & 556 & 63.3 & \\
\hline$\geq 1$ year & 175 & 17.3 & 119 & 68.0 & \\
\hline
\end{tabular}

"P-value from chi-square test. 
lence was observed among hypertensive women $(\mathrm{p}<0.001)$, women with scabies/pediculosis ( $\mathrm{p}$ $=0.002)$, and women with overweight/obesity ( $\mathrm{p}$ $=0.039$ ) (Table 2).

Table 3 shows higher prevalence of CMD among women who do not practice physical activity on a daily basis $(\mathrm{p}=0.001)$ and among smokers $(p=0.006)$. The prevalence observed in those who reported using tranquilizers was 81.9\% ( $<<0.001)$.

Table 4 presents the prevalence of CMD according to types of violence suffered in the year before incarceration. Except for physical aggression in childhood/adolescence, it is possible to see that all the variables were positively associated with presence of common mental disorder $(\mathrm{p}<0.05)$.

Through the multiple logistic regression analysis of the factors associated with CMD presented on Table 5, it was possible to verify that the following variables showed an independent and positive association with CMD: absence of income, arterial hypertension, scabies/pediculosis, smoking, physical inactivity, use of tran-

Table 2. Prevalence of common mental disorder (CMD) according to self-reported morbidity and weight gain among female inmates of a prison in the interior of the State of São Paulo, 2011/2013.

\begin{tabular}{|c|c|c|c|c|c|}
\hline \multirow{2}{*}{ Variables and categories } & \multicolumn{2}{|c|}{ Inmates $(n=1,013)$} & \multicolumn{2}{|c|}{ CMD $(\geq 8)$} & \multirow{2}{*}{ P-value ${ }^{*}$} \\
\hline & n & $\%$ & $\mathbf{n}$ & $\%$ & \\
\hline Arterial hypertension ${ }^{*}$ & & & & & $<0.001$ \\
\hline No & 785 & 78.3 & 498 & 63.4 & \\
\hline Yes & 217 & 21.6 & 168 & 77.4 & \\
\hline Diabetes ${ }^{\star}$ & & & & & 0.781 \\
\hline No & 970 & 96.8 & 644 & 66.4 & \\
\hline Yes & 32 & 3.2 & 22 & 68.8 & \\
\hline Heart problem & & & & & 0.933 \\
\hline No & 906 & 91.0 & 600 & 66.2 & \\
\hline Yes & 90 & 9.0 & 60 & 66.7 & \\
\hline Gynecological problem & & & & & 0.901 \\
\hline No & 668 & 65.9 & 446 & 66.8 & \\
\hline Yes & 343 & 34.1 & 229 & 66.4 & \\
\hline Vaginal bleeding & & & & & 0.415 \\
\hline No & 947 & 93.5 & 628 & 66.3 & \\
\hline Yes & 66 & 6.5 & 47 & 71.2 & \\
\hline Urinary tract infection & & & & & 0.322 \\
\hline No & 695 & 68.8 & 456 & 65.6 & \\
\hline Yes & 314 & 31.2 & 216 & 68.8 & \\
\hline Fractures & & & & & 0.158 \\
\hline No & 656 & 64.8 & 427 & 65.1 & \\
\hline Yes & 357 & 35.2 & 248 & 69.5 & \\
\hline Tuberculosis & & & & & 0.496 \\
\hline No & 981 & 97.1 & 651 & 66.4 & \\
\hline Yes & 29 & 2.9 & 21 & 72.4 & \\
\hline Hansen's disease & & & & & 0.838 \\
\hline No & 998 & 98.7 & 664 & 66.5 & \\
\hline Yes & 13 & 1.3 & 9 & 69.2 & \\
\hline IST/AIDS & & & & & 0.104 \\
\hline No & 895 & 88.5 & 588 & 65.7 & \\
\hline Yes & 116 & 11.5 & 85 & 73.3 & \\
\hline Scabies/Pediculosis & & & & & 0.002 \\
\hline No & 761 & 75.2 & 488 & 64.1 & \\
\hline Yes & 251 & 24.8 & 187 & 74.5 & \\
\hline Overweight/obesity & & & & & 0.039 \\
\hline No & 404 & 39.9 & 254 & 62.9 & \\
\hline Yes & 609 & 60.1 & 421 & 69.1 & \\
\hline
\end{tabular}

P-value from chi-square test. 
Table 3. Prevalence of common mental disorder (CMD) according to lifestyle, use of tranquilizers and illicit drugs among female inmates of a prison in the interior of the State of São Paulo, 2011/2013.

\begin{tabular}{|c|c|c|c|c|c|}
\hline \multirow{2}{*}{ Variables and categories } & \multicolumn{2}{|c|}{ Inmates $(n=1,013)$} & \multicolumn{2}{|c|}{ CMD $(\geq 8)$} & \multirow{2}{*}{ P-value } \\
\hline & $\mathbf{n}$ & $\%$ & $\mathbf{n}$ & $\%$ & \\
\hline Physical activity $\geq 30 \mathrm{~min} /$ day & & & & & 0.001 \\
\hline No & 712 & 70.3 & 497 & 69.8 & \\
\hline Yes & 301 & 29.7 & 178 & 59.1 & \\
\hline Smoking & & & & & 0.006 \\
\hline No & 309 & 30.5 & 187 & 60.6 & \\
\hline Yes & 704 & 69.5 & 488 & 69.3 & \\
\hline Use of tranquilizers in prison ${ }^{*}$ & & & & & $<0.001$ \\
\hline No & 816 & 80.6 & 514 & 63.0 & \\
\hline Yes & 193 & 19.1 & 158 & 81.9 & \\
\hline Risky sexual behavior ${ }^{*}$ & & & & & 0.960 \\
\hline No & 740 & 73.2 & 493 & 66.7 & \\
\hline Yes & 271 & 26.8 & 181 & 66.8 & \\
\hline Use of illicit drugs before imprisonment & & & & & 0.481 \\
\hline No & 381 & 37.6 & 259 & 68.0 & \\
\hline Yes & 632 & 62.4 & 416 & 65.8 & \\
\hline
\end{tabular}

Table 4. Prevalence of common mental disorder (CMD) according to types of violence suffered before imprisonment among female inmates of a prison in the interior of the State of São Paulo, 2011/2013.

\begin{tabular}{|c|c|c|c|c|c|}
\hline \multirow{2}{*}{ Variables and categories } & \multicolumn{2}{|c|}{ Inmates $(\mathrm{n}=1,103)$} & \multicolumn{2}{|c|}{ CMD $(\geq 8)$} & \multirow{2}{*}{ P-value ${ }^{*}$} \\
\hline & n & $\%$ & $\mathbf{n}$ & $\%$ & \\
\hline $\begin{array}{l}\text { Psychological violence in the year before being } \\
\text { imprisoned }\end{array}$ & & & & & $<0.001$ \\
\hline No & 605 & 59.7 & 366 & 60.5 & \\
\hline Yes & 408 & 40.3 & 309 & 75.7 & \\
\hline Physical violence in the year before being imprisoned & & & & & $<0.001$ \\
\hline No & 695 & 68.6 & 434 & 62.4 & \\
\hline Yes & 318 & 31.4 & 241 & 75.8 & \\
\hline Sexual violence in the year before being imprisoned & & & & & 0.020 \\
\hline No & 934 & 92.2 & 613 & 65.6 & \\
\hline Yes & 79 & 7.8 & 62 & 78.5 & \\
\hline $\begin{array}{l}\text { Before the age of } 15 \text { she witnessed physical aggression in } \\
\text { the family }\end{array}$ & & & & & 0.013 \\
\hline No & 592 & 58.4 & 376 & 63.5 & \\
\hline Yes & 421 & 41.6 & 299 & 71.0 & \\
\hline $\begin{array}{l}\text { Before the age of } 15 \text { she suffered physical aggression in } \\
\text { the family }\end{array}$ & & & & & 0.870 \\
\hline No & 740 & 73.1 & 492 & 66.5 & \\
\hline Yes & 273 & 26.9 & 183 & 67.0 & \\
\hline
\end{tabular}

${ }^{*}$ P-value from chi-square test.

quilizers, having witnessed violence in the family during childhood/adolescence, and having suffered psychological violence in the year before being incarcerated.

\section{Discussion}

The prevalence of symptoms related to common mental disorder (CMD) affects more than half of the incarcerated women investigated in the present study $(66.7 \%)$. 
Table 5. Multiple logistic regression analysis of the factors associated with common mental disorder (CMD) among female inmates of a prison in the interior of the State of São Paulo, 2011/2013.

\begin{tabular}{|c|c|c|c|c|c|c|c|c|c|c|c|c|}
\hline \multirow{2}{*}{ Variables } & \multicolumn{3}{|c|}{ First Stage } & \multicolumn{3}{|c|}{ Second Stage } & \multicolumn{3}{|c|}{ Third Stage } & \multicolumn{3}{|c|}{ Fourth Stage } \\
\hline & OR & $95 \% \mathrm{CI}$ & P-value & OR & $95 \% \mathrm{CI}$ & P-value & OR & 95\%CI & P-value & OR & 95\%CI & P-value \\
\hline \multicolumn{13}{|c|}{ Receives income } \\
\hline No & 1.37 & $1.04-1.80$ & 0.023 & & & & & & & & & \\
\hline Yes & 1 & & & & & & & & & & & \\
\hline \multicolumn{13}{|c|}{ Arterial Hypertension } \\
\hline No & & & & 1 & & & & & & & & \\
\hline Yes & & & & 1.99 & $1.38-2.86$ & $<0.001$ & & & & & & \\
\hline \multicolumn{13}{|c|}{ Scabies/ Pediculosis } \\
\hline No & & & & 1 & & & & & & & & \\
\hline Yes & & & & 1.65 & $1.19-2.89$ & 0.003 & & & & & & \\
\hline \multicolumn{13}{|l|}{ Smoking } \\
\hline No & & & & & & & 1 & & & & & \\
\hline Yes & & & & & & & 1.58 & $1.18-2.11$ & 0.002 & & & \\
\hline \multicolumn{13}{|c|}{ Physical Activity } \\
\hline No & & & & & & & 1 & & & & & \\
\hline Yes & & & & & & & 1.56 & $1.19-2.13$ & 0.002 & & & \\
\hline \multicolumn{13}{|c|}{ Use of Tranquilizer } \\
\hline No & & & & & & & 1 & & & & & \\
\hline Yes & & & & & & & 2.41 & $1.61-3.61$ & $<0.001$ & & & \\
\hline \multicolumn{13}{|c|}{ Witnessed violence in the family in childhood/adolescence } \\
\hline No & & & & & & & & & & 1 & & \\
\hline Yes & & & & & & & & & & 1.40 & $1.05-1.86$ & 0.021 \\
\hline \multicolumn{13}{|c|}{ Suffered psychological violence in the year before imprisonment } \\
\hline No & & & & & & & & & & 1 & & \\
\hline Yes & & & & & & & & & & 1.89 & $1.14-2.53$ & $<0.001$ \\
\hline
\end{tabular}

Hosmer-Lemeshow Test $=0.88$

A study carried out in 2006 in the State of São Paulo identified a significant prevalence of mental disorders in the incarcerated population: $61.7 \%$ of the inmates had at least one occurrence of mental disorder during their lifetime, and approximately $25 \%$ of the ones who were in the closed prison system met diagnostic criteria for at least one mental disorder in the year before the study. Approximately $11.2 \%$ of the male inmates and $25.5 \%$ of the women presented severe mental disorders ${ }^{14,15}$.

The participants' profile in the present study was: young, single, non-white women with low social and/or economic status, incomplete primary education, low professional qualification, informal and low-income labor activity previously to the imprisonment. Specific studies with the incarcerated population have confirmed these findings and have showed that a large part of the sample of incarcerated women, in addition to these characteristics, had a life history marked by material, educational and affective insufficiency ${ }^{12,16-18}$.

The factors that were associated with CMD were: prior psychological violence, witnessed violence in the family in childhood/adolescence use of tranquilizers, self-reported arterial hypertension and scabies/pediculosis, being a smoker, physical inactivity and absence of income.

The environment in prisons is usually precarious and unhealthy. Overcrowded cells, poor diets, lack of hygiene, sedentary lifestyle, drug use and conflicts of many types configure conditions that favor the proliferation of epidemics and other sickening situations. There is a considerable prevalence of cases of IST/AIDS, tuberculosis, pneumonia, dermatosis, hepatitis, traumas, infectious diarrhea, arterial hypertension, diabetes and mental disorders. Corroborating the literature, this study found that the living conditions before incarceration and the experience in the 
prison contribute to the high prevalence of common mental disorder ${ }^{5,18,19}$.

Studies have shown that more than half of all prisoners use licit and/or illicit drugs, have mental illness, or both the conditions apply. This increases their risk of sexually transmitted diseases and other infections, all of them highly prevalent in the incarcerated population. Furthermore, it is estimated that around $40 \%$ of all prisoners have at least one chronic disease, like diabetes or arterial hypertension, although it is a population that is predominantly composed of youths ${ }^{6,8,10,20}$.

The prevalence of tobacco use is high in the FP and positively associated with CMD; however, no action has been carried out in order to control the incarcerated women's tobacco use, despite the existence of resources in the public networks of healthcare services ${ }^{21,22}$.

A study conducted in the United States with people who received a psychiatric diagnosis found that their chance of smoking was 3.23 (95\%CI 3.11-3.35) times higher when compared to those without this diagnosis. Improving the approach to psychiatric comorbidities - smoking among them - can be a task to be undertaken with the incarcerated population, considering that prisons can become adequate places for the implementation of actions of health promotion and disease prevention ${ }^{3}$.

With regard to the practice of physical activity, only one third of the women practiced some modality on a daily basis. The evidences of the benefits of physical activities during at least thirty minutes in the major part of the weekdays are clear and consistent, as they contribute to mental health, not to mention their physical-functional and socialization benefits ${ }^{23}$.

The bibliographic review has not found studies that assessed the relationship between physical activity and common mental disorder among incarcerated women. Nevertheless, population-based studies have found an inverse relationship between practice of physical activity and presence of $\mathrm{CMD}^{24,25}$.

The prison where the study was conducted has a yard for the common use of the inmates. This yard can be used for daily, systematic and guided physical activities, in the perspective of acquisition of new behaviors that enhance physical and mental health.

Violence seems to be part of the incarcerated women's history and produces negative experiences throughout their lives. The women who reported having suffered psychological violence in the year before being imprisoned and having witnessed psychological violence in the family during adolescence had a chance almost twice as high of manifesting common mental disorder when compared to the other women. This corroborates the findings of a study in which personal history of psychological violence was also associated with $\mathrm{CMD}^{25}$. Therefore, incarcerated women may present a psychological condition that is even more vulnerable due to the history of violence and to the current condition of imprisonment ${ }^{3,25}$.

Historically, prisons have been organized to shelter men, who represent the majority in the prison system. Until recently, incarcerated women were admitted to the same institutions constructed for men. These were transformed into female prisons, as is the case of the prison studied here. The fragile adaptation of the old structures has not met the needs of the population of incarcerated women, and this has been aggravating the conditions of permanence in prison and, due to this, the health of the women ${ }^{26,27}$.

The incarcerated population's extremely precarious conditions of life and health make us reflect that, although the objective is ensuring their return to social life, the hazardous conditions of confinement become an obstacle to rehabilitation and prevent the imprisoned people's access to health in an effective way ${ }^{27,28}$.

Among the study's limitations, we would like to mention that the data may be underestimated and the prevalence may be even higher. Many participants may not have reported stories of abuses or may have denied involvement with drugs and alcohol, fearing that the study might negatively affect their legal situation. Another limitation is the fact that it was a cross-sectional study, a condition that prevents the establishment of implicit causality relations among the variables. Moreover, we did not have access to the women's mental health conditions before their imprisonment.

\section{Final remarks}

The study has shown the difficult mental health situation of women incarcerated in the researched institution and corroborates other studies related to this population profile. The identification of the presence of mental problems when the individuals are admitted to prisons is a necessary task that may guide the adoption of measures to reduce suffering beyond the penalty of deprivation of freedom. 
In this perspective, basic actions targeted at the treatment of common diseases, like arterial hypertension and dermatological complaints, the possibility of practicing physical activities on a regular basis, and the opportunity to work while serving the sentence need to be implemented. In addition, the treatment of mental disorders must be adequately conducted, including drug administration. These approaches need to be included in a health policy for the incarcerated population, in the context of a broader policy of reorganization of the prison system in Brazil.

\section{Collaborations}

CAF Audi participated in the study's conception and planning, coordinated and participated in the collection and analysis of the empirical data, wrote the paper and approved its final version. SM Santiago participated in the study's conception and planning, supervised data collection and analyses, reviewed the paper critically and approved its final version. MGG Andrade participated in the paper's conception, in the critical review and approved the final version of the paper. PMSB Francisco participated in the statistical analysis and interpretation of the data, and approved the final version of the paper. 


\section{References}

1. World Health Organization (WHO). The World Health Report-mental health: new understanding, new hope. Geneva: WHO; 2002.

2. Goldberg D, Huxley P. Common mental disorders: a biosocial model. London: Tavistock; 1992.

3. Rich JD, Cortina CS, Uvin ZX, Dumont DM (2013) Women, Incarceration and Health. Women's Health Issues 2013 ; 23(6):333-334.

4. World Health Organization (WHO). Obesity Preventing and Managing the Global Epidemic. Report of WHO Consultation on Obesity. Programme of Nutrition. Family and Reproductive Health. Geneva: WHO; 1998.

5. World Health Organization (WHO). European Office. Health in prisons - a WHO guide to the essentials in prison health. Copenhagen: WHO; 2007.

6. Fazel S, Danesh J. Serious mental disorder in 23000 prisoners: a systematic review of 62 surveys. Lancet 2002; 359(9306):545-550.

7. Meltzer HGB, Petticrew M. The Prevalence of Psychiatric Morbidity among Adults Aged 16-64, Living in Private Households, in Great Britain. London: Office of Population Censuses and Surveys; 1994.

8. Reed J. Mental health care in prisons. Br J Psychiatry 2003; 182:287-288.

9. Chandra PS, Satyanarayana VA. Gender disadvantage and common mental disorders in women. Int Rev Psychiatry 2010; 22(5):513-524.

10. Fazel S, Hayes AJ, Bartellas K, Clerici M, Trestman R. Mental health of prisoners: prevalence, adverse outcomes, and interventions. Lancet Psychiatry 2016; 3(9):871-881.

11. Moraes PAC, Dalgalarrondo P. Incarcerated women in São Paulo: mental health and religiosity. J Bras Psiquia$\operatorname{tr} 2006$; 55(1):50-56.

12. Beusenberg M, Orley JA. Users Guide to the Self Reporting Questionnaire (SRQ). Geneva: World Health Organization; 1994.

13. Mari JJ, Willians P. A validity study of a psychiatric screening questionnaire (SRQ-20) in primary care in the city of São Paulo. Br J Psychiatry 1986; 148:23-26.

14. Gonçalves DM, Stein AT, Kapczinski F. Performance of the Self-Reporting Questionnaire as a psychiatric screening questionnaire: a comparativestudy with Structured Clinical Interview for DSM-IV-TR. Cad Saude Publica 2008; 24(2):380-390.

15. Damas BF, Oliveira WF. Mental health in prisons of Santa Catarina, Brazil. Brazilian Journal Mental Health 2013; 5(12):1-24.

16. Canazaro D, Argimon IIL. Characteristics, depressive symptoms, and associated factors in incarcerated women in the State of Rio Grande do Sul, Brazil. Cad Saude Publica 2010; 26(7):1323-1333.

17. Covington SS. Women and the Criminal Justice System. Women's Health Issues 2007; 17(4):180-182.

18. Staton M, Leukefeld C, Webster JW. Substance use, health problems and service utilization among incarcerated women. Int J Offender Ther Comp Criminol 2003; 47(2):224-239.
19. Alves J, Dutra A, Maia A. History of adversity, health and psychopathology among prisoners: comparison between men and women. Cien Saude Colet 2013; 18(3):701-709.

20. Instituto Nacional de Câncer José Alencar Gomes da Silva (INCA). A situação do tabagismo no Brasil: dados dos inquéritos do Sistema Internacional de Vigilância, da Organização Mundial da Saúde, realizados no Brasil, entre 2002 e 2009. Rio de Janeiro: INCA; 2011.

21. Iglesias R, Prabhat JHA, Pinto M, Silva VLC, Godinho J. Discussion paper - health, nutrition and population (HNP) Tobacco control in Brazil : executive summary. Epidemiol. Serv. Saúde 2008; 17(4):301-304.

22. Brazil. Ministry of Health (MH). Agita Brazil: National Program for Promotion of Physical Activity. Brasilia: MH; 2002. (Series C. Projects, Programs and Reports; n. 63).

23. Rocha SV, Araújo TM, Almeida MMG, Virtuoso JS. Practice of physical activity during leisure time and common mental disorders among residents of a municipality of Northeast Brazil. Rev Brasileira de Epidemiologia 2012; 15(4):871-883.

24. Pereira ARS, Morita M, Barros MBA. Common mental disorder. In: Barros MBA, César CLGC, Carandina L, Goldbaum M, editors. The health dimensions: a population-based study in Campinas, SP. São Paulo: Aderaldo \& Rothschild; 2008. p. 143-152.

25. Johnson H. Concurrent Drug and Alcohol Dependency and Mental Health Problems among Incarcerated Women [online].Australian and New Zealand Journal of Criminology 2006; 39(2):190-217. [acessado 2016 Maio 2]. Disponível em: http://search.informit.com.au/documentSummary; $\mathrm{dn}=811595735840921$; res=IELHSS

26. Fernandes LH, Alvarenga CW, Santos LL, Pazin FA. The need to improve health care in prisons. Rev Saude Publica 2014; 48(2):275-283.

27. Bergh BJ, Gatherer A, Fraser A, Moller R. Imprisonment and women's health: concerns about gender sensitivity, human rights and public health. Bull World Health Organ 2011; 89(9):689-694.

28. Gois SM, Santos JHPO, Silveira MFA, Gaudêncio MMP. Beyond bars and punishments: a systematic review of prison health. Cien Saude Colet 2012; 17(5):1235-1246.

Artigo apresentado em 17/08/2016

Aprovado em 22/03/2017

Versão final apresentada em 24/03/2017 